\title{
Expectation of variance due to mitochondrial genes from several mating designs
}

\author{
M.F. ROTHSCHILD ${ }^{(*)}$ and L. OLLIVIER ${ }^{(* *)}$ \\ $\left(^{*}\right)$ Department of Animal Science, lowa State University Ames, lowa 50011 U.S.A. \\ (**) I.N.R.A., Station de Génétique quantitative et appliquée, \\ Centre de Recherches de Jouy-en-Josas, F 78350 Jouy-en-Josas.
}

\begin{abstract}
Summary
Genetic variation due to non-nuclear DNA has been generally ignored by animal breeders. Recent evidence has confirmed that mitochondrial inheritance is predominantly of maternal origin in mammals. Advances in biotechnology make manipulation of non-nuclear and nuclear material in embryos likely in the future. Estimation of the relative importance of direct, maternal and mitochondrial genetic variation would help in assessing the value of these new technologies. Expectations of causal components of variance from previously used mating and crossfostering designs are modified to include variation due to mitochondrial (cytoplasmic) material. The efficiencies of the designs are compared, as well as the statistical consequences of adding the mitochondrial component to the original models. The designs presented have limitations due to possible confounding of maternal, grand-maternal and mitochondrial effects and to their being not adequate for all animal species and traits. However techniques such as embryo transfer can circumvent those difficulties. Possibilities of using improved designs clearly depend on biotechnological advances and on the cost of implementing those new techniques.
\end{abstract}

Key words: Mitochondrial inheritance, direct and maternal genetic variances, covariances.

\author{
Résumé \\ Espérance de la variance due à des gènes mitochondriaux \\ dans divers plans d'accouplement
}

La variation génétique due à l'ADN extra-nucléaire a généralement été ignorée en génétique animale. Des résultats récents confirment que l'hérédité mitochondriale est, d'une manière prédominante, d'origine maternelle chez les mammifères. Les progrès de la biotechnologie permettront vraisemblablement à l'avenir de manipuler le matériel nucléaire et extra-nucléaire de l'embryon. De ce fait, l'estimation de l'importance relative de la variation génétique directe, maternelle et mitochondriale peut servir à mieux évaluer l'intérêt de ces nouvelles techniques. Les espérances des composantes causales de variance dans des plans d'accouplements et d'adoptions croisées utilisés précédemment sont modifiées pour inclure la variation d'origine mitochondriale (cytoplasmique). Les efficacités des dispositifs expérimentaux sont comparées, ainsi que les conséquences statistiques de l'ajout de la composante mitochondriale au modèle originel. Les plans présentés se heurtent à des limites dues à des confusions possibles entre les effets maternels, grand-maternels et mitochondriaux, et à leur inadaptation à certaines espèces animales ou à certains caractères. Cependant des techniques comme le transfert d'embryons permettent de contourner ces difficultés. La possibilité d'utiliser des dispositifs expérimentaux améliorés dépend essentiellement de progrès en biotechnologie et du coût de mise en cuvre de ces nouvelles techniques.

Mots clés : Hérédité mitochondriale, variances et covariances génétiques directes et maternelles. 


\section{Introduction}

Maternal effects on traits expressed in offspring have been the subject of numerous studies (Koch \& ClaRK, 1955 ; Cox et al., 1959 ; Willham, 1963 ; EISEN, 1967 ; Robison, 1972 ; Rutledge, 1980 ; Riska et al., 1985a, b). Particular emphasis has been placed on estimation of maternal components of variance (WILLHAM, 1963, 1972 ; EISEN, 1967 ; ThOMPSON, 1976 ; RISKA et al., 1985a) and problems associated with their effect on selection response (FALCONER, 1965 ; Foulley \& LEFORT, 1978 ; RoBison, 1981).

Consideration of maternal effects as directed through cytoplasmic inheritance, including mitochondrial DNA, has been generally ignored or received only passing mention. EISEN (1967) lists cytoplasmic inheritance as a possible source of covariance among animals of a similar maternal line but excludes estimation of the variance due to that source. RoBISON (1972) and WAGNER (1972) both suggested that mitochondria may play a role in maternal effects.

Central to the problem of estimation of variance due to mitochondrial DNA or cytoplasmic genes is the mode of inheritance. Mitochondrial DNA is known to be maternally inherited in animals (Brown, 1980 ; HAYASH et al., 1978 ; Giles et al., 1980 ; GYLLENSTEN et al., 1985). Amount of mitochondrial DNA of paternal origin after 8 generations of backcrossing in mice was estimated to be only .0017 (GYLLENSTEN et al., 1985). Mitochondrial DNA evolves at a higher rate than nuclear DNA (BRown et al., 1979 ; LAIPIS \& HAuswirTh, 1980 ; Clayton, 1982). This evolution could be expected to reduce the covariance among relatives in the same maternal line over time but no estimation of this effect exists. Another possible source of reduction of the covariance among relatives is the heterogeneity of mtDNA in an individual. However the present evidence is in favor of homogeneity within individual organisms (AvISE \& LANSMAN, 1983 ; Boursot \& Bonhomme, 1986).

Evidence cited for the role of cytoplasmic effects includes differences in traits from reciprocal crosses (BRUMBY, 1960 ; BERESKIN \& TOUCHBERRY, 1966 ; ROBISON et al., 1981 ; DZAPO and WASSMUTH, 1983) and lower heritability estimates from paternal halfsister correlations than from daughter-dam regressions (RENDEL et al., 1957 ; VAN Vleck and Bradford, 1965 ; Seykora \& MC Daniel, 1983). Methods of analysis to quantify these cytoplasmic effects have lagged. BRUMBY (1960) used crossing of lines in a reciprocal manner to determine the extent of cytoplasmic effects. BeLl et al. (1985) and Huizinga et al. (1986) used an analytical approach by categorizing females by maternal line of descent. They used analysis of variance procedures to estimate the percent of variation explained by maternal line. BeLl et al. (1985) and Huizinga et al. (1986) estimated these effects to be from 2 to $10 \mathrm{p}$. 100 of the total phenotypic variation for a number of milk production traits and concluded these effects are probably mitochondrial (cytoplasmic). An alternative approach would be to design an experiment or calculate from field data covariances among relatives to estimate the variation due to mitochondrial or cytoplasmic inheritance. The purpose of this paper is to present such a method. 


\section{Method}

Consider the following model to explain phenotypic variation :

$\sigma_{p}^{2}=\sigma_{A_{0}}^{2}+\sigma_{A_{m}}^{2}+\sigma_{D_{0}}^{2}+\sigma_{D_{m}}^{2}+\sigma_{C}^{2}+\sigma_{M T}^{2}+\sigma_{A_{0} A_{m}}+\sigma_{D_{0} D_{m}}+\sigma_{W}^{2}$

where

$\sigma_{\mathrm{p}}^{2} \quad=$ total phenotypic variance,

$\sigma_{A_{0}}^{2} \quad=$ direct additive genetic variance,

$\sigma_{\mathrm{D}_{0}}^{2}=$ direct dominance variance,

$\sigma_{A_{m}}^{2} \quad=$ maternal additive genetic variance,

$\sigma_{D_{m}}^{2} \quad=$ maternal dominance variance,

$\sigma_{\mathrm{C}}^{2}=$ common environmental (maternal and pen) variance,

$\sigma_{\mathrm{MT}}^{2} \quad=$ mitochondrial (non-nuclear) variance,

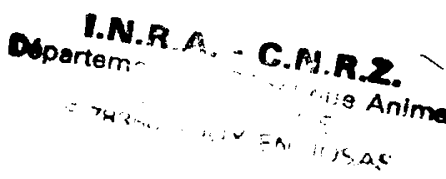

$\sigma_{\mathrm{A}_{\mathrm{o}} \mathrm{A}_{\mathrm{m}}}=$ direct-maternal additive genetic covariance,

$\sigma_{D_{0} D_{m}}=$ direct-maternal dominance covariance and

$\sigma_{\mathrm{w}}^{2} \quad=$ residual environmental variance.

Unlike previous models (Willham, 1963, 1972 ; Eisen, 1967 ; Riska et al., 1985a, b) which accounted for both direct and maternal genetic variances and covariances, this model also includes variance due to mitochondrial (cytoplasmic) genes. Rules for determining the expectations of these covariances among relatives and individuals are given by Willham (1963, 1972) and the expectations are given in EISEN (1967). Expectations of covariances involving genetic variance due to mitochondrial genes $\left(\sigma_{\mathrm{MT}}^{2}\right)$ are obtained assuming no mutation, no influence of heterogeneity and no paternal influence on inheritance of mitochondrial genes. Therefore covariances among relatives linked by maternal line of inheritance have expectation of one $\sigma_{\mathrm{MT}}^{2}$ and those whose relationship comes from sires have an expectation of zero $\sigma_{\mathrm{MT}}^{2}$. This is simply illustrated
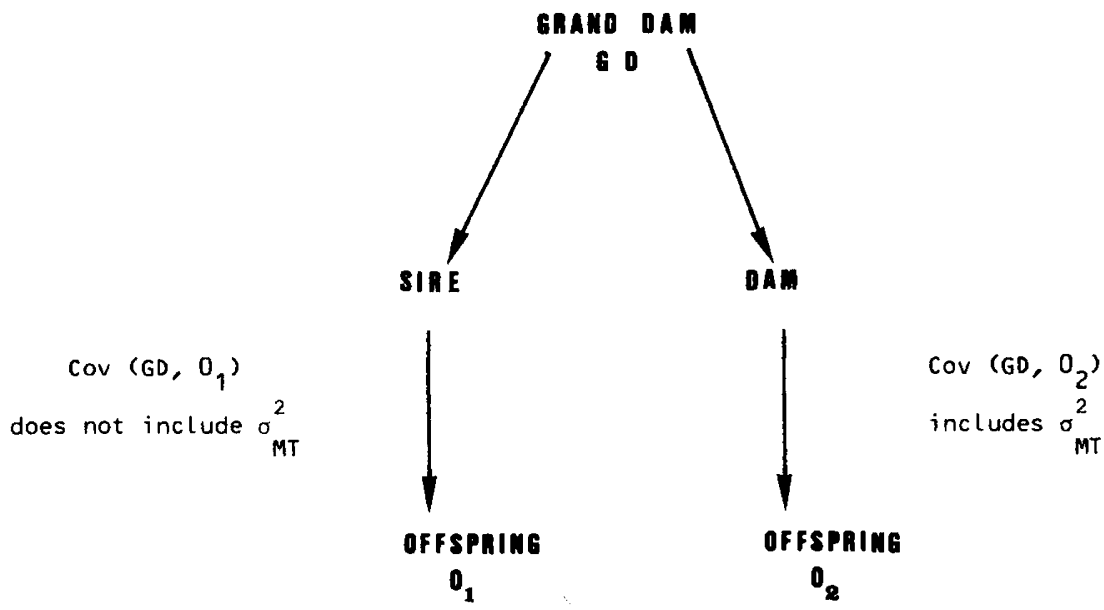

Fig. 1

Illustration of the expectation of covariance between grand dam and offspring from 2 different paths of descent. 
in figure 1. Following this example, expectations of covariances among relatives and individuals from 3 mating designs (EISEN, 1967) and a crossfostering design (RisKA et al., 1985a) were modified to include $\sigma_{M T}^{2}$ as a causal component of variance. Expectations of many of those covariances between relatives (excluding $\sigma_{\mathrm{MT}}^{2}$ ) have also been previously presented by Willham $(1963,1972)$. Development and specific discussion concerning these designs are in each respective publication. Actual estimation of these components is discussed in EISEN (1967) and in RISKA et al. (1985a).

In order to compare the various designs and to evaluate the consequences of adding the mitochondrial component to the original models, the information matrices

TABLE 1

Theoretical expectations of covariances between relatives in the 3 mating designs of EISEN (1967).

\begin{tabular}{|c|c|c|c|c|c|c|c|c|c|c|c|c|}
\hline \multirow{2}{*}{ Covariance $\left(P_{x}, P_{y}\right)$} & \multicolumn{9}{|c|}{ Causal components ${ }^{\text {(a) }}$} & \multicolumn{3}{|c|}{$\begin{array}{l}\text { Mating } \\
\text { Design }\end{array}$} \\
\hline & $\sigma_{\mathrm{A}_{0}}^{2}$ & $\sigma_{D_{0}}^{2}$ & $\sigma_{\mathrm{A}_{0} \mathrm{~A}_{\mathrm{m}}}$ & $\sigma_{D_{0} D_{m}}$ & $\sigma_{A_{m}}^{2}$ & $\sigma_{D_{m}}^{2}$ & $\sigma_{\mathrm{C}}^{2}$ & $\sigma_{\mathrm{MT}}^{2}$ & $\sigma_{w}^{2}$ & I & II & III \\
\hline Paternal half-sibs $\ldots \ldots$ & $1 / 4$ & 0 & 0 & 0 & 0 & 0 & 0 & 0 & 0 & $*$ & $*$ & $*$ \\
\hline $\begin{array}{c}\text { Single first cousins (sires } \\
\text { full-sibs) } \ldots \ldots \ldots \ldots \ldots\end{array}$ & $1 / 8$ & 0 & 0 & 0 & 0 & 0 & 0 & 0 & 0 & $*$ & & \\
\hline $\begin{array}{l}\text { Paternal half-sibs plus sin- } \\
\text { gle first cousins (dams } \\
\text { full-sibs) } \ldots \ldots \ldots \ldots \ldots\end{array}$ & $3 / 8$ & $1 / 8$ & $1 / 2$ & 0 & $1 / 2$ & $1 / 4$ & 0 & 1 & 0 & $*$ & * & $*$ \\
\hline $\begin{array}{c}\text { Three-quarter sibs }(\text { dams } \\
\text { paternal half-sibs) }\end{array}$ & $5 / 16$ & $1 / 16$ & $1 / 4$ & 0 & $1 / 4$ & 0 & 0 & 0 & 0 & $*$ & & $*$ \\
\hline $\begin{array}{l}\text { Double first cousins (sires } \\
\text { full-sibs and dams full- } \\
\text { sibs) } \ldots \ldots \ldots \ldots \ldots \ldots \ldots\end{array}$ & $1 / 4$ & $1 / 16$ & $1 / 2$ & 0 & $1 / 2$ & $1 / 4$ & 0 & 1 & 0 & $*$ & & \\
\hline $\begin{array}{l}\text { Single first cousins (sires } \\
\text { full-sibs) plus half first } \\
\text { cousins (dams paternal } \\
\text { half-sibs) } \ldots \ldots \ldots \ldots \ldots\end{array}$ & $3 / 16$ & $1 / 32$ & $1 / 4$ & 0 & $1 / 4$ & 0 & 0 & 0 & 0 & $*$ & & \\
\hline Full-sibs $\ldots \ldots \ldots$ & $1 / 2$ & $1 / 4$ & 1 & 0 & 1 & 1 & 1 & 1 & 0 & * & $*$ & $*$ \\
\hline Within full-sibs $\ldots \ldots \ldots$ & $1 / 2$ & $3 / 4$ & 0 & 0 & 0 & 0 & 0 & 0 & 1 & * & * & $*$ \\
\hline Dam-offspring $\ldots \ldots \ldots$ & $1 / 2$ & 0 & $5 / 4$ & 1 & $1 / 2$ & 0 & 0 & 1 & 0 & $*$ & $*$ & * \\
\hline Sire-offspring $\ldots \ldots \ldots$ & $1 / 2$ & 0 & $1 / 4$ & 0 & 0 & 0 & 0 & 0 & 0 & $*$ & * & * \\
\hline $\begin{array}{l}\text { Maternal aunt }- \text { nephew } \\
\text { (or niece) } \ldots \ldots \ldots \ldots\end{array}$ & $1 / 4$ & 0 & $3 / 4$ & $1 / 4$ & $1 / 2$ & 0 & 0 & 1 & 0 & $*$ & $*$ & * \\
\hline $\begin{array}{l}\text { Maternal half aunt (pater- } \\
\text { nal half sibs ) - nephew } \\
\text { (or niece) } \ldots \ldots \ldots \ldots\end{array}$ & $1 / 8$ & 0 & $1 / 4$ & 0 & 0 & 0 & 0 & 0 & 0 & $*$ & & * \\
\hline $\begin{array}{l}\text { Paternal uncle (or aunt) - } \\
\text { nephew (or niece) } \ldots\end{array}$ & $1 / 4$ & 0 & $1 / 4$ & 0 & 0 & 0 & 0 & 0 & 0 & $*$ & $*$ & $*$ \\
\hline $\begin{array}{l}\text { Double first cousins (oppo- } \\
\text { site sexes full-sibs) } \ldots \ldots\end{array}$ & $1 / 4$ & $1 / 16$ & $1 / 2$ & 0 & 0 & 0 & 0 & 0 & 0 & & * & $*$ \\
\hline $\begin{array}{c}\text { Single first cousins (dams } \\
\text { full-sibs) } \ldots \ldots \ldots \ldots \ldots\end{array}$ & $1 / 8$ & 0 & $1 / 2$ & 0 & $1 / 2$ & $1 / 4$ & 0 & 1 & 0 & & $*$ & \\
\hline $\begin{array}{c}\text { Half first cousins } \text { (dams } \\
\text { paternal half-sibs) } \ldots\end{array}$ & $1 / 16$ & 0 & $1 / 4$ & 0 & $1 / 4$ & 0 & 0 & 0 & 0 & & & * \\
\hline
\end{tabular}

(a) Components described in Model 1. Variances and covariances for direct and maternal effects presented in WillHAM (1963) and EISEN (1967). 
$\left(X^{\prime} X\right)$ are inverted and the diagonal elements of $\left(X^{\prime} X\right)^{-1}$ used as criteria of statistical efficiency, following the suggestion made by EISEN (1967). Relative efficiencies are expressed as inverse ratios of the diagonal elements of the designs being compared.

\section{Results}

The modified expectations in the mating designs of EISEN (1967) are presented in table 1. For example, the covariance between paternal aunt or uncle and nephew or niece does not contain in its expectation $\sigma_{\mathrm{MT}}^{2}$ but the covariance between maternal aunt and nephew does contain $\sigma_{M T}^{2}$. Use of crossfostering data to estimate $\sigma_{M T}^{2}$ is also possible as seen in table 2. Note that the design used in table 2 (RISKA et al., 1985a) is not able to separate common litter and maternal dominance variance $\left(\sigma_{D_{m}+C}^{2}\right)$. It also assumes only postnatal effects, hence $\sigma_{\mathrm{MT}}^{2}$ is confounded with prenatal effects. The difference between the covariances of sire and offspring and offspring and dam where offspring is nursed by an unrelated female has expectation $\sigma_{\mathrm{MT}}^{2}$. This may provide a simplified design to estimate $\sigma_{\mathrm{MT}}^{2}$ when other components of variance are not desired.

Using EISEN's criteria of statistical efficiency described above to compare the various designs, it appears that his mating design II will not allow estimation because of colinearity between $\sigma_{\mathrm{MT}}^{2}, \sigma_{\mathrm{C}}^{2}$ and $\sigma_{\mathrm{A}_{\mathrm{m}}}^{2}$, the determinant of $\left(\mathrm{X}^{\prime} \mathrm{X}\right)^{-1}$ being close to zero.

TABLE 2

Theoretical expectations of covariances from the crossfostering design of RISKA et al. (1985).

\begin{tabular}{|c|c|c|c|c|c|c|c|}
\hline \multirow[b]{2}{*}{ Covariance $\left(P_{x}, P_{y}\right)$} & \multicolumn{7}{|c|}{ Causal components ${ }^{\text {(a) }}$} \\
\hline & $\sigma_{A_{0}}^{2}$ & $\sigma_{D_{0}}^{2}$ & $\sigma_{\mathrm{A}_{\mathrm{l}, \mathrm{A}_{\mathrm{m}}}}$ & $\sigma_{A_{m}}^{2}$ & $\sigma_{D_{m}+C}^{2}$ & $\sigma_{\mathrm{MT}}^{2}$ & $\boldsymbol{\sigma}_{\mathrm{w}}^{2}$ \\
\hline Sire-Offspring & $1 / 2$ & 0 & $1 / 4$ & 0 & 0 & 0 & 0 \\
\hline Offspring-Nurse (nurse $\neq$ dam) $\ldots$ & 0 & 0 & $1^{\text {(b) }}$ & $1 / 2$ & 0 & 0 & 0 \\
\hline Offspring-dam (dam $\neq$ nurse) & $1 / 2$ & 0 & $1 / 4$ & 0 & 0 & 1 & 0 \\
\hline Offspring-dam (dam $=$ nurse) & $1 / 2$ & 0 & $5 / 4$ & $1 / 2$ & 0 & 1 & 0 \\
\hline Full-sibs $($ dam $=$ nurse $) \ldots$ & $1 / 2$ & $1 / 4$ & 1 & 1 & 1 & 1 & 0 \\
\hline Full-sibs $($ dam $\neq$ nurse $) \ldots \ldots$ & $1 / 2$ & $1 / 4$ & 0 & 1 & 1 & 1 & 0 \\
\hline $\begin{array}{l}\text { Full-sibs (one nursed by dam, } \\
\text { other by unrelated nurse) } \ldots\end{array}$ & $1 / 2$ & $1 / 4$ & $1 / 2$ & 0 & 0 & 1 & 0 \\
\hline $\begin{array}{l}\text { Two unrelated individuals nursed } \\
\text { by same dam (genetic dam of } \\
\text { one of them) } \ldots \ldots \ldots \ldots \ldots\end{array}$ & $\mathbf{0}$ & 0 & $1 / 2$ & 1 & 1 & 0 & 0 \\
\hline $\begin{array}{l}\text { Two unrelated individuals each } \\
\text { nursed by dam of the other }\end{array}$ & 0 & 0 & 1 & 0 & 0 & 0 & 0 \\
\hline Within full-sibs $\ldots \ldots \ldots \ldots$ & $1 / 2$ & $3 / 4$ & 0 & 0 & 0 & 0 & 1 \\
\hline
\end{tabular}

a) Components described in model 1 . Variances and covariances for direct and maternal effects presented by RisKa et al. (1985a).

b) Instead at 0.75 in the original paper. 
The results given in table 3 show how the addition of the mitochondrial component reduces the efficiency of estimation of the other components. Most affected are the maternal genetic and common environmental effects in the designs of table 1 , and direct genetic effects in the crossfostering design of table 2.

\section{TABLE 3}

Relative efficiency of the mating designs used to estimate mitochondrial variance (based on the diagonal elements of inverse information matrix).

\begin{tabular}{c|c|c|c}
\hline \hline \multirow{2}{*}{$\begin{array}{c}\text { Causal } \\
\text { component }\end{array}$} & \multicolumn{2}{|c|}{ Mating designs of table 1 } & \multirow{2}{*}{$\begin{array}{c}\text { Mating design } \\
\text { of table 2 }\end{array}$} \\
\cline { 2 - 3 } & I & III & 4.7 \\
\hline MT & $1^{(b)}$ & 1.4 & 0.42 \\
$A_{o}$ & $0.96^{(c)}$ & 0.93 & 0.79 \\
$D_{o}$ & 0.65 & 0.76 & 1 \\
$A_{o} A_{m}$ & 0.96 & 0.81 & - \\
$D_{o} D_{m}$ & 0.97 & 0.97 & 0.95 \\
$A_{m}$ & 0.58 & 0.63 & 0.94 \\
$D_{m}$ & 0.35 & 0.49 & 0.60 \\
$C$ & 0.27 & 0.40 & \\
W & 0.61 & 0.74 & \\
\hline
\end{tabular}

(a) Components described in (1).

(b) Efficiency expressed relative to design I of table 1.

(c) Efficiency expressed relative to the original model excluding mitochondrial variance.

\section{Discussion}

From a theoretical standpoint the inclusion of $\sigma_{M T}^{2}$ in expectations of the covariances is extremely straightforward. It may have more intuitive appeal for litter-bearing species when compared to the analytical approach used by BELL et al. (1985) and Huizinga et al. (1986) to estimate the percent of variation due to cytoplasmic inheritance. These designs require nonoverlapping generations, no repeat matings, full sibs, and measurement of the trait in both sexes. This of course is impossible for milk production traits. In addition, the requirement of planning and executing crossfostering experiments or collection of data from such varied relatives as used in mating designs by EISEN (1967) is often not possible. Adaptation of these designs to estimate $\sigma_{\mathrm{MT}}^{2}$ also requires that the relatives in the mating groups in each design have no foundation females in common. That may be difficult to satisfy. Another difficulty mentioned by EISEN (1967) and RisKA et al. (1985a) is that covariances between the observational components exist and should be considered when solving for the components.

Perhaps as important is the consideration of other effects. Extension of these results to a grand-maternal model (WillHAM, 1972) or a model with persistent environ- 
mental effects (RISKA et al., 1985b) is not straightforward. Also ignored here is the covariance that exists between nuclear DNA and mitochondrial DNA. An example of this covariance is the control of antigen expression by mitochondria while the structural gene for the antigen is under nuclear control (Goodfellow, 1983). However the expectations presented here with $\sigma_{M T}^{2}$ allow for estimation of the relative amount of phenotypic variation explained by non-nuclear DNA. This could then be considered when estimating response to selection or, if superior mitochondrial DNA lines could be identified, in selection of dams for producing future offspring.

It should also be stressed that the inclusion of an additional causal component has a non-negligible effect on the estimation of the others components, both in terms of sampling variance (tabl. 3) and of actual estimate. This is illustrated by reanalyzing the data of Riska et al., (1985a). The results, given in table 4, show that model 1 applied to their data reveals a significant mitochondrial (or prenatal) component, which, together with an increase of the residual variance, leads to an important reduction in the estimates for direct genetic effects.

TABLE 4

Comparison of 2 models applied to the data of Riska et al. (1985a).

\begin{tabular}{|c|c|c|}
\hline \multirow{2}{*}{ Component ${ }^{(a)}$} & \multicolumn{2}{|c|}{ Estimation model $^{\left({ }^{b}\right)}$ (estimate \pm s.e.) } \\
\hline & (A) & (B) \\
\hline$\sigma_{A_{0}}^{2}$ & $115 \pm 26$ & $54 \pm 33$ \\
\hline$\sigma_{\mathrm{D}_{0}}^{2}$ & $45 \pm 84$ & $-96 \pm 97$ \\
\hline$\sigma_{\mathrm{A}_{0} \mathrm{~A}_{m}}$ & $-17 \pm 25$ & $-17 \pm 25$ \\
\hline$\sigma_{A_{m}}^{2}$ & $97 \pm 59$ & $62 \pm 60$ \\
\hline$\sigma_{D_{m}+C}^{2}$ & $-39 \pm 55$ & $-4 \pm 56$ \\
\hline$\sigma_{M T}^{2}$ & - & $66 \pm 23$ \\
\hline$\sigma_{\mathrm{E}}^{2}$ & $318 \pm 62$ & $454 \pm 78$ \\
\hline * & 519 & 519 \\
\hline
\end{tabular}

(a) Components described in (1).

(b) A : model of RisKA et al. (1985a), with correction given in table 2.

B : model (1).

These designs, being limited to litter-bearing species and to traits measured in both sexes, are not adequate for all species. This obviously is the case for dairy cattle in particular. However, given the advances in biotechnology, the above designs can be modified to estimate $\sigma_{\mathrm{MT}}^{2}$. The most obvious improvement would be the use of embryo transfer. This technique could be used to obtain the full-sib families $(\mathrm{Q} 1, \mathrm{Q} 2, \mathrm{Q} 3)$ required in EISEN's designs. Depending on an appropriate choice of recipient mothers, and measuring one offspring per dam (thus excluding full-sib covariance), model 1 will only include direct genetic and mitochondrial variation. As one can expect, the reduced model, including only 4 causal components, allows a considerable increase in efficiency 
of estimation of $\sigma_{\mathrm{MT}}^{2}$. It can be shown, for instance, using the criterion defined for table 3, that, even ignoring sire-offspring covariance in order to include sex-limited traits, the designs I, II and III of table 1 thus modified are, respectively, 12.2, 12.6 and 10.4 times more efficient than design I with the full model. Embryo transfer may also be used in the design of table 2 to crossfoster early in prenatal life, as suggested by RISKA et al. (1985a), thus avoiding the confounding of mitochondrial and prenatal effects.

More remote possibilities may also be envisaged, such as transfer of nuclei, allowing for instance to estimate the two covariances between identical twins produced artificially and placed in the same or different cytoplasmic (mitochondrial) environment. The difference of these covariances would yield a direct estimate of $\sigma_{\mathrm{MT}}^{2}$. Possibilities of these modified designs clearly depend on the emergence of biotechnological advances and on their costs. However, given recent findings concerning the apparent importance of non-nuclear DNA for some traits, determination of variation due to non-nuclear DNA as outlined here is warranted.

Received December 3, 1985. Accepted September 22, 1986.

\section{Acknowledgements}

M.F. Rothschild gratefully acknowledges the support he received from the I.N.R.A. Station de Génétique quantitative et appliquée, Domaine de Vilvert, 78350 Jouy-en-Josas, France during his sabbatical leave from Iowa State University.

Suggestions made by referees are also gratefully acknowledged.

\section{References}

Avise J.C., Lansman R.A., 1983. Polymorphism of mitochondrial DNA in populations of higher animals. In : NeI M., KoEHN R.K. (eds), Evolution of genes and proteins, 147-164, Sinauer Associates, Sunderland, Mass.

Bell B.R., MC Daniel B.T., Robison O.W., 1985. Effect of cytoplasmic inheritance on production traits of dairy cattle. J. Dairy Sci., 68, 2038-2051.

Bereskin B., TouchberRY R.W., 1966. Crossbreeding in dairy cattle. III. First lactation production. J. Dairy Sci., 49, 659-667.

Boursot P., Bonhomme F., 1986. Génétique et évolution du génome mitochondrial des Métazoaires. Génét. Sél. Evol., 18, 73-98.

Brown W.M., 1980. Polymorphism in mitochondrial DNA of humans as revealed by restriction endonuclease analysis. Proc. Nat. Acad. Sci., 77, 3605-3609.

Brown W.M., George M.Jr., Wilson A.C., 1979. Rapid evolution of animal mitochondrial DNA. Proc. Nat. Acad. Sci., 76, 1967-1971.

Brumby P.J., 1960. The influence of the maternal environment on growth in mice. Heredity, 14, $1-18$.

Clayton D.A., 1982. Replication of animal mitochondrial DNA. Cell, 28, 693-705.

Cox D.F., Legates J.E., Cockerham C.C., 1959. Maternal influence on body weight. J. Anim. Sci., 18, 519-527.

Dzapo V., Wassmuth R., 1983. Mitochondrialer Stoffwechsel und heterotische Effekte beim Schwein. Ergebnisse eines reziproken Kreuzungsversuches. 2. Atmungsaktivität und oxydative Phosphorylierung in Herz -, Leber- und Hodenmitochondrien. Z. Tierz. Züchtungsbiol., 100, 280-295. 
EISEN E.J., 1967. Mating designs for estimating direct and maternal genetic variances and directmaternal genetic covariances. Can. J. Genet. Cytol., 9, 13-22.

Falconer D.S., 1965. Maternal effects and selection response. In: GeERTs S.J. (ed.), Genetics today, Proc. XIth Int. Cong. Genet., The Hague, Sept. 1963, 3, 763-774, Pergamon Press, Oxford.

Foulley J.L., Lefort G., 1978. Méthodes d'estimation des effets directs et maternels en sélection animale. Ann. Génét. Sél. Anim., 10, 475-496.

Giles R.E., Blanc H., Cann H.M., Wallace C., 1980. Maternal inheritance of human mitochondrial DNA. Proc. Nat. Acad. Sci., 77, 6715-6719.

Goodfellow P., 1983. Mitochondria and the major histocompatibility complex. Nature, 306, 539540.

Gyllensten U., Wharton D., Wilson A.C., 1985. Maternal inheritance of mitochondrial DNA during backcrossing of two species of mice. J. Heredity, 76, 321-324.

Hayashi J., Yonekawa H., Gotoh O., Watanabe J., Tagashira Y., 1978. Strictly maternal inheritance of rat mitochondrial DNA. Biochem. Biophys. Res. Comm., 83, 1032-1038.

Huizinga H.A., Korver S., Mc Daniel B.T., Politiek R.D., 1986. Maternal effects due to cytoplasmic inheritance in dairy cattle. Influence on milk production and reproduction traits. Livest. Prod. Sci., 15, 11-26..

Косн R.M., Clark R.T., 1955. Genetic and environmental relationships among economic characters in beef cattle. III. Evaluation of maternal environment. J. Anim. Sci., 14, 979-996.

LAIPIS P.J., HAUSWIRTH W.W., 1980. Variation in bovine mitochondrial DNAs between maternally related animals : In : KROON A.M., SACcONE C. (eds), Organization and expression of mitochondrial genome, 125-130. Elsevier, North Holland.

Rendel J.M., Robertson A., Asker A.A., Kishim S.A., Ragab M.T., 1957. The inheritance of milk production characteristics. J. Agric. Sci., 48, 426-432.

Riska B., Rutledge J.J., Atchley W.R., 1985a. Genetic analysis of crossfostering data with sire and dam records. J. Heredity, 76, 247-250.

Riska B., Rutledge J.J., Atchley W.R., 1985b. Covariance between direct and maternal genetic effects in mice, with a model of persistent environmental influences. Genet. Res., 45, 287-297.

Robison O.W., 1972. The role of maternal effects in animal breeding. V. Maternal effects in swine. J. Anim. Sci., 35, 1303-1315.

Robison O..W., 1981. The influence of maternal effects on the efficiency of selection; a review. Livest. Prod. Sci., 8, 121-137.

Robison O.W., Mc Daniel B.T., Rincon E.J., 1981. Estimation of direct and maternal additive and heterotic effects from crossbreeding experiments in animals. J. Anim. Sci., 52, 44-50.

RutLedge J.J., 1980. Fraternity size and swine reproduction. Effect on fecundity of gilts. 2. Genetical consequences. J. Anim. Sci., 51, 868-874.

Seykora A.J., Mc Daniel B.T., 1983. Heritabilities and correlations of lactation yields and fertility in Holsteins. J. Dairy Sci., 66, 1486-1493.

Thompson R., 1976. The estimation of maternal genetic variance. Biometrics, 32, 903-917.

VAN Vleck L.D., Bradford G.E., 1965. Comparison of heritability estimates from daughter-dam regression and paternal half-sib correlations. J. Dairy Sci., 48, 1372-1375.

WAGNER R.P., 1972. The role of maternal effects in animal breeding. II. Mitochondria and animal inheritance. J. Anim. Sci., 35, 1280-1287.

WiLlham R.L., 1963. The covariance between relatives for characters composed of components contributed by related individuals. Biometrics, 19, 18-27.

Willham R.L., 1972. The role of maternal effects in animal breeding. III. Biometrical aspects of maternal effects in animals. J. Anim. Sci., 35, 1288-1293. 